WALDEMAR GLABISZEWSKI DOROTA GREGO-PLANER

\title{
Abilities to exploit newly- acquired technologies as a source of competitive advantage of finance companies in Poland
}

\section{Introduction}

Innovative technologies currently seem to be the main determinant of companies' competitiveness, especially in the case of such an innovative sector of activity as the financial one. It turns out that in the time of ever-present dynamic changes it is very difficult to singlehandedly create unique solutions concerning the manners of operating, thus their primary source appears to be broadly understood surroundings, with transfer being its most common form of acquisition. The factor which determines the effectiveness of technology transfer is the company's absorption potential, within which one can most often notice the abilities to acquire and adopt new technology, possibly also to modify and improve it. Much

Waldemar Glabiszewski, Ph.D. Faculty of Economic Sciences and Management Nicolaus Copernicus University in Toruń

Dorota Grego-Planer, Ph.D. Faculty of Economic Sciences and Management Nicolaus Copernicus University in Toruń less frequently, the abilities distinguished within this potential are the ones allowing for effective and efficient exploitation of new technology. Thus, the role of shaping effective instruments of competition is not appreciated and is omitted in the process of company's development.

Due to that reason, in this paper the Authors attempt to briefly describe the essence and significance of the specialized segment of 
absorption potential, which is constituted by the abilities to exploit technologies newly-acquired from an external source. In particular, an attempt is made to answer the question: to what extent the development of those skills influences the size of competitive advantage built up by companies in the Polish sector of commercial finance services.

\section{The essence, structure and role of the ability to exploit newly-acquired technologies}

Due to their enormous significance to the development of companies, as well as whole economies, technologies, their transfer as well as the ability to make it are a frequent topic of academic analyses and discussions. Unfortunately, it has not resulted in the creation of an unambiguous and universally accepted perception of those issues. In this paper, technology is a widely-understood term denoting all types of transformations from inputs to outputs and all technological devices required for that purpose (Rutka 2002, p. 195). On the other hand, technology transfer (TT) - according to the approach by P. Trott - simply means applying a particular technology for a new purpose or by a new user (Trott 2008, p. 323) or, specifying according to T. Agmon and M. A. von Glinow (1991, p. 1) - using technology for new purposes or by a new user in order to gain economic profits. TT understood in such a manner may involve a very wide spectrum of action, which is why it is difficult to unambiguously pinpoint the borders within which it occurs. According to the perception of the TT process which is dominant in literature, from the perspective of its recipient the process boils down to three basic, although internally diverse and structured stages, namely to (Cohen, Levinthal 1990, p. 128):

- acquiring new technology,

- assimilating the acquired technology,

- using the assimilated technology.

The process thus does not end - as it may seem - at the moment of choosing and purchasing or acquiring a technology, or even at the moment of its implementation, but also involves its exploitation, which is full absorption aimed at reaching the acquired goals. For the final stage of TT, it is often impossible to clearly define a particular moment at which and because of which the TT may be considered as complete. As a rule, however, the TT process is completed at the moment of the destined use of the transferred technology by the recipient, which means the use allowing for generating the desired effects (Lasserre 2003, p. 273). Although it seems the least complex, as it is all about proper launching 
and exploiting the acquired technology, it is actually, apart from the assimilation which conditions it, the stage of technology absorption which is crucial and crowning, and which ultimately determines the success of the whole process. It is at this stage that the mechanisms of efficient, effective and pro-market use of the newly-acquired technology are launched, and the final verification of its usability and realization of goals set at the moment of making a decision to undertake TT occurs. According to W.M. Grudzewski, I.K. Hejduk (2008, p. 171), the stage involves launching a new process and systematic checking of its proper realization. Thus, when concluding a process of acquiring new technology, one should construct an instrumentarium which will ensure:

- its swift progress,

- effective exploitation,

- generating the results which are desired by the market.

Exploitation of technology itself is a very important, but first of all obligatory stage of its transfer, as it is the factor that makes it possible to gain a return on the whole investment. Contrary to what it might seem, this stage requires many more measures taken in the course of realization of the planning, organizing, motivating and controlling function. It is not about only launching a technology and confirming technological efficiency, but also about creating a managing infrastructure as a result of making use of the newly-introduced technology. As a consequence, there is a need for the required skills and great commitment of the specialists employed by the recipient of technology.

The abilities to exploit a newly-acquired technology constitute- apart from the ability to possess and assimilate it- the segment of a company's pro-technological absorption skills, in accordance with the dependencies presented in figure 1.

Taking into account the fact that particular segments of absorption abilities account for carrying out subsequent stages of TT, it would seem that one should define the sequential dependencies occurring among them, within which the ability to acquire technology influences the ability to assimilate it, and the ability to assimilate influences the ability to use it. In practice, however, it is impossible to set clear borders between them, as they are often created jointly by means of the same assets universally used in the TT process. Even in the theoretical approach, some abilities are difficult to separate from one another, especially the ability to assimilate technology from the ability to exploit it. The latter - in the most general sense - is supposed to ensure such use of a technology which will make it possible to generate the effects desired for the process launched, and which in consequence allow a company to reach the planned market-economic goals. 


\section{Absorption potential in TT}

Ability to assimilate the acquired technology

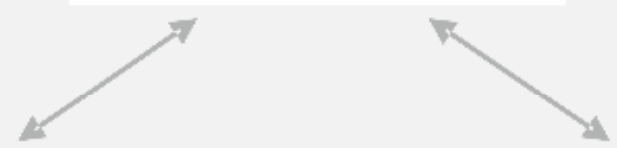

Ability to acquire new technology

Ability to exploit the introduced technology

Figure 1. Segments of absorption potential in the $\pi$ process

Source: own study

Such results, however, should not be expected without deliberate employment of the ability to assimilate, including especially the adaptation and improvement of technology. Apart from that - theoretically speaking - there is a dilemma: is the ability to exploit technology used in a company to improve technology after its launch, or is it the ability to assimilate it again? In economic reality, however, it is of little importance, as in practice a company musters all its assets to carry out such a task effectively, including the abilities to exploit and assimilate, as well as the ones characteristic of the R\&D sector - not necessarily categorizing them. What is more, all of them may be de facto concentrated and used in one organizational unit of a given company (For more details see: Glabiszewski 2016, pp. 166-173).

The abilities to exploit implemented technologies should, due to their use, include:

- the ability to efficiently exploit implemented technologies for the intended purpose,

- the ability to efficiently exploit new technologies,

- the ability to generate the outcomes desired by the market by means of new technologies.

The task of those abilities is not only to result in carrying out routine operations after reaching the planned technological parameters (Lowe 1999, 
p. 165) or to ensure technological efficiency, but also to establish complex managing infrastructure (Lasserre 2003, p. 273) and connections with various systems, especially quality management. Even the technical preparation of the process is not purely technical in its nature, as the issues are closely related to the organizational and economic ones, forming an inseparable whole (Pasternak 2005, p. 232).

However, in order to ensure a company's abilities to carry out such demanding tasks, specific components should be acquired or shaped, both of individual (personal) nature, the carrier of which are particular employees, as well as related to general organization, which constitute the organizational capital of the whole company (Barney 1997, p. 144). Among specialized personal assets, which determine the abilities to use the technology acquired from an external source, but are not universal components of the absorption potential, the Authors points to the significance of:

- knowledge of the technological processes taking place in a company,

- knowledge and experience of employees in terms of exploiting technology,

- knowledge concerning the rules of identifying, shaping and mapping processes,

- motivation to report irregularities in processes,

- motivation to act efficiently and effectively.

Among the specialized assets related to general organization which are characteristic of the area of the potential responsible for exploiting newlyacquired technologies, the Authors predicts:

- knowledge concerning the capabilities of the technology in the company's possession,

- knowledge of optimal conditions of exploiting the technologies available within an organization,

- clear and comprehensive procedures of carrying out processes,

- clear and understandable technical documentation,

- quality control system,

- process improvement system,

- linking employee control system with the motivational one,

- process orientation in company management,

- process measurement system, designed to evaluate their effectiveness,

- flexibility of technological processes due to changes in customers' expectations and preferences.

While shaping individual components of the abilities to exploit the acquired technology, it should be remembered that gaining competitive advantage and 
good results in the process of competition on the basis of the technology is ultimately dependent on the degree of its development (Wiśniewska 2015, p. 138). It is thus them that play a significant role not only in the TT process, but in the whole activity of an organization, influencing its market and financial position.

\section{Methodology and hypotheses}

The empirical part of the article was written on the basis of the research done by the Author in 2014-2015 with the use of an online survey and the CSAQ technique - Computerized Self-Administered Questionnaire (see: Tourangeau, Conrad, Couper 2013, pp. 59-60). It was sent to the heads of 155 commercial companies of the finance sector registered in Poland, namely all banks, property and life insurance companies, investment funds (TFI) and universal fund management companies (PTE). Eventually, 108 entities took part in the study by filling in the online survey questionnaire. They constituted $70 \%$ of the studied population. As a result, measurement and analysis was conducted for 37 TFIs, 26 banks, 19 property insurance companies, 17 life insurance companies and 9 PTEs.

The studies conducted constituted a primary source of data, essential for carrying out the main empirical aim of the article, namely the evaluation of the influence of the Polish finance companies' abilities to exploit newly-acquired technologies on gaining a competitive advantage. For reaching thusly formulated goal, the Authors set three specific objectives, namely:

- to evaluate the influence of the aggregated area of abilities to exploit newlyacquired technologies on gaining competitive advantage in market conditions in comparison to other areas of the absorption potential,

- to evaluate the influence of specific segments of the abilities to exploit newlyacquired technology on gaining competitive advantage in market conditions,

- to evaluate the influence of individual components of the abilities to exploit newly-acquired technologies on gaining competitive advantage in market conditions.

In order to carry out the specific objectives, as well as the article's primary objective, the Authors put forward for verification three following research hypotheses:

H1. The degree of development of finance companies' ability to make use of transferred technologies has an equally significant influence on gaining a competitive advantage as the degree of development of the ability to assimilate the acquired technologies.

H2. All three segments of finance companies' abilities to exploit newly-acquired 
technologies have a significant impact on gaining a competitive advantage. $\mathrm{H} 3$. Both individual assets, as well as the ones related to organization in general which jointly constitute specialized abilities to exploit newly-acquired technology have a significant impact on gaining a competitive advantage.

In order to verify the above hypotheses, the Authors conducted statistical and descriptive analyses of the obtained findings, reaching the conclusions presented in the subsequent section.

\section{The abilities to exploit acquired technology in relation to competitive advantage of finance companies}

A company's abilities to exploit newly-acquired technology constitute one of the three segments of the absorption potential used in the TT process, which should coherently allow for introducing innovative technologies to a company. The technology, in turn, should become a source of competitive advantages, allowing for reaching market and financial objectives which were the foundations of the decision to implement it.

In the course of study, a vast majority of as many as $70 \%$, which was 76 entities questioned, declared that as a result of innovative absorption they had managed to achieve technological superiority over their direct rivals. It should be noted, however, that having an advantage in the domain of assets is sensible only when it can be shaped into an advantage in the market domain, which means that it has to be expressed by the identified attributes of the company's market offer which are of such great value to the customers that they will result in purchasing it. In order to check whether the abovementioned finance companies were successful in completing this task, their managers were asked to define the percentage of gaining market advantages constructed as a rule on the basis of technological assets advantages. The obtained average at the level of $67.7 \%$ indicates that the studied companies were successful in gaining competitive advantages in market conditions, although not as significant as they had expected. However, taking into account especially high level of competition in the finance sector, the advantages gained should be perceived as a worthy achievement.

It is at this point that an important question appears about the influence that a company's financial capabilities to exploit newly-acquired technologies have on gaining competitive advantages. In order to answer it, in the first years Pearson correlation coefficients were calculated for the level of development of those skills as well as the level of gaining market competitive advantages diagnosed in the course of studies. It should be added that the

41

WALDEMAR GLABISZEWSKI

DOROTA GREGO-PLANER 
assessment of the degree of development of all absorption abilities in the analyzed companies was conducted by means of percentage scale, that is from 0 to $100 \%$, where 0 meant that given abilities were not developed at all, whereas $100 \%$ meant that they were developed to the maximum. The obtained values of coefficients, which were presented in Table 1, indicate that there is a positive correlation between those variables. It thus turns out that further development of absorption abilities should ensure a higher level of competitive advantage to finance companies, which they expect to gain as a result of TT process, although to a rather limited extent.

Table 1. Pearson correlation coefficients for the degree of development of absorption abilities and the degree of gaining competitive advantages in the market

\begin{tabular}{l|c}
\hline \multirow{2}{*}{ Variables } & $\begin{array}{c}\text { The degree of gaining } \\
\text { competitive advantage } \\
\text { in the market }\end{array}$ \\
\cline { 2 - 2 } & $r$ \\
\hline The degree of development of the ability to acquire new technologies & $0,504^{\dagger}$ \\
\hline The degree of development of the ability to assimilate new technologies & $0,624^{\dagger}$ \\
\hline The degree of development of the ability to use assimilated technologies & $0,443^{\dagger}$ \\
\hline
\end{tabular}
${ }^{*} p \leq 0,1 ;{ }^{* *} p \leq 0,05 ;{ }^{* * *} p \leq 0,01 ;{ }^{\dagger} p \leq 0,001$

Source: own study based on survey results

A strong dependence $(\mathrm{r}=0.62)$ occurs not only between the degree of gaining competitive advantages in the market and the degree of development of the ability to assimilate technology. In relation to the degree of development of the ability to acquire new technologies and the ability to use them, the dependence is merely moderate in its nature (see: Wasilewska 2008, p. 236). The diagnosed problem of correlation thus constitutes the basis to falsify the assumed hypothesis $\mathrm{H1}$, as it turns out that a higher level of development of the ability to assimilate newly-acquired technologies does increase the finance companies' effectiveness in building up competitive advantage, whereas the development of the ability to exploit the acquired technologies does not produce such clear results. The outcome may seem somewhat surprising, as it is at the stage of assimilating technology that its possible improvements are assumed, which provides the 
opportunity to increase its innovativeness level, forming an important basis for building up competitive advantage.

In order to deepen the knowledge concerning the studied dependences, at the next stage Pearson correlation coefficients were estimated for the degree of development of three identified segments of finance companies' abilities to exploit acquired technologies and the degree of gaining competitive advantages by them diagnosed in the course of research. Their values were presented in table 2 .

Table 2. Pearson correlation coefficients for the degree of developments of segments of exploitation abilities and the degree of gaining competitive advantage in the market

\begin{tabular}{l|c}
\multicolumn{1}{c|}{ Variables } & $\begin{array}{c}\text { The degree of gaining } \\
\text { competitive advantage } \\
\text { in the market }\end{array}$ \\
\cline { 2 - 2 } & $r$ \\
\hline $\begin{array}{l}\text { The degree of development of the ability to effectively exploit implemented } \\
\text { technologies for their intended purposes }\end{array}$ & $0,451^{\dagger}$ \\
\hline $\begin{array}{l}\text { The degree of development of the ability to effectively exploit implemented } \\
\text { technologies for their intended purposes }\end{array}$ & $0,389^{\dagger}$ \\
\hline $\begin{array}{l}\text { The degree of development of the ability to generate desired market outcomes by } \\
\text { means of implemented technologies }\end{array}$ & $0,336^{\dagger}$ \\
\hline
\end{tabular}

${ }^{*} p \leq 0,1 ;{ }^{* *} p \leq 0,05 ;{ }^{* * *} p \leq 0,01 ;{ }^{\dagger} p \leq 0,001$

Source: own study based on survey results

The level of diagnosed correlation indicates that there is a relatively weak linear connection between the analyzed variables, which means that also in the case of hypothesis $\mathrm{H} 2$ there is a basis for its falsification. In fact, it is only the degree of development of the ability to effectively exploit implemented technologies for their intended purpose - and only to a limited extent - that influences the competitive advantages gained by companies. Such a result raises a number of doubts both of practical and theoretical nature, encouraging further studies and analyses aimed at explaining those surprising results, as the awareness of the lack of strong dependences in the analyzed area may discourage managers from improving pro-technological exploitation abilities in their companies, which seems rather risky. It thus appears even more justified to verify in detail the 
existence of the influence of specialized components of the abilities to exploit technologies on building up competitive advantage. That is why the level of Pearson correlation coefficients for those variables was calculated and presented in table 3.

Table 3. Pearson correlation coefficients for the degree of development of particular components of exploitation abilities and the degree of gaining competitive advantage in the market

\begin{tabular}{|c|c|c|}
\hline \multirow[t]{2}{*}{ Lp. } & \multirow[t]{2}{*}{ Variables } & $\begin{array}{c}\text { The degree of gaining } \\
\text { competitive advantage in } \\
\text { the market }\end{array}$ \\
\hline & & $r$ \\
\hline & Employees' individual assets & $0,610^{\dagger}$ \\
\hline 1 & $\begin{array}{l}\text { Knowledge concerning the rules of identifying, shaping and } \\
\text { mapping processes }\end{array}$ & $0,576^{\dagger}$ \\
\hline 2 & Motivation for efficient and effective action & $0,566^{\dagger}$ \\
\hline 3 & Motivation to report irregularities in processes & $0,531^{\dagger}$ \\
\hline 4 & $\begin{array}{l}\text { Knowledge of the technological processes functioning within a } \\
\text { company }\end{array}$ & $0,448^{\dagger}$ \\
\hline \multirow[t]{2}{*}{5} & $\begin{array}{l}\text { Employees' knowledge and experience concerning exploiting } \\
\text { technology }\end{array}$ & $0,277^{\star \star *}$ \\
\hline & Assets related to general organization & $0,685^{\dagger}$ \\
\hline 1 & Link between employee control system with the motivational one & $0,769^{\dagger}$ \\
\hline 2 & Clear and understandable technical documentation & $0,615^{\dagger}$ \\
\hline 3 & Clear and comprehensive procedures of carrying out processes & $0,601^{\dagger}$ \\
\hline 4 & $\begin{array}{l}\text { Knowledge concerning the optimum conditions of exploiting the } \\
\text { technologies available to the organization }\end{array}$ & $0,585^{\dagger}$ \\
\hline 5 & Process improvement system & $0,531^{\dagger}$ \\
\hline 6 & $\begin{array}{l}\text { Flexibility of technological processes due to changes in } \\
\text { customers' expectations and preferences }\end{array}$ & $0,559^{\dagger}$ \\
\hline 7 & Process orientation in company management & $0,526^{\dagger}$ \\
\hline 8 & Quality control system & $0,520^{\dagger}$ \\
\hline
\end{tabular}




\begin{tabular}{r|l|c}
9 & Quality management system & $0,506^{\dagger}$ \\
\hline 10 & $\begin{array}{l}\text { Process measurement system aimed at evaluating their } \\
\text { effectiveness }\end{array}$ & $0,385^{\dagger}$ \\
\hline 11 & $\begin{array}{l}\text { Knowledge of the capabilities of the technologies in the } \\
\text { organization's possession }\end{array}$ & $0,121^{*}$ \\
\hline${ }^{*} p \leq 0,1 ;{ }^{* *} p \leq 0,05 ;{ }^{* * *} p \leq 0,01 ;{ }^{\dagger} p \leq 0,001$ &
\end{tabular}

Source: own study based on survey results

Evaluating the values of Pearson correlation coefficients allows for confirming the validity of hypothesis $\mathrm{H} 3$, as both the averaged degree of development of the assets which are individual in their nature and of those which relate to general organization, constituting specialized abilities to exploit newly-acquired technologies has a significant influence on gaining competitive advantages in market conditions $(r>0.6)$. It turns out that a more thorough analysis allows to notice more prominent dependences occurring among the analyzed categories of abilities and advantages.

Such a situation concerning the components related to general organization stems primarily from the strong correlation between employee control system with the motivational one, as well as clear and understandable technical documentation and clear and comprehensible procedures of carrying out processes. Those components on the one hand motivate, and on the other facilitate effective use of new technologies, thus they obviously influence the process of gaining an advantage. However, knowledge of the capabilities of the technologies in the organization's possession alone - as it appears - does not provide grounds for gaining market superiority over rivals, which is hardly surprising, unlike the diagnosed little influence of the process measurement system, aimed at evaluating their effectiveness. In the area of individual assets, on the other hand, the force of dependences between particular components and the gained competitive advantages seems rather limited, apart from the less important employees' knowledge and experience concerning exploiting technology. As it turns out, it is not an asset which is sublime enough to ensure superiority over market rivals.

\section{Conclusion}

Abilities to exploit newly-acquired technologies, which constitute an important component of the absorption potential, are responsible for 
demanding and significant tasks in the TT process. Supported by the abilities to acquire and assimilate innovative technologies they should ensure their use in the course of processes carried conducted by a company in order to generate effects that would serve as evidence of gaining a competitive advantage in market conditions. The assumption, despite being seemingly justified, was called into question by means of the findings presented in this article, obtained in the course of research conducted among finance organizations operating in Poland. As it turns out, the development of abilities to exploit transferred technologies hardly determines the extent of competitive advantages gained in the market. This influence was confirmed as moderate at most when isolated segments of exploitation abilities were evaluated. It was not until a more detailed analysis of specialized components of the abilities to exploit new technologies was conducted that it was possible to notice a stronger dependence related to gaining competitive advantage, yet still not in the case of all the components studied.

The intriguing and at times surprising findings emphasize the need to undertake further, more detailed studies concerning the role of the abilities to exploit newly-acquired technologies in the TT process, which constitute an integral part of a company's absorption potential.

\section{Summary}

Abilities to exploit newly-acquired technologies as a source of
competitive advantage of finance companies in Poland The article of empirical nature is an attempt to evaluate the influence of the abilities to exploit newly acquired technologies possessed by finance companies operating in Poland on the competitive advantages they gain. The findings obtained confirm the existence of such influence, although its force seems rather moderate. A stronger influence was noted in relation to the jointly analyzed individual components, as well as the one related to general organization, which constitute the exploitation abilities, as well as in relation to three basic specialized assets within this type of abilities.

Keywords: absorptive capacity, technology transfer, competitive advantage, abilities. 


\section{Streszczenie}

\section{Zdolności do eksploatowania nowo pozyskiwanych technologii jako źródło przewagi konkurencyjnej przedsiębiorstw finansowych w Polsce}

Niniejszy artykuł o empirycznym charakterze stanowi próbę oceny wpływu posiadanych przez działające w Polsce przedsiębiorstwa finansowe zdolności do eksploatowania nowo pozyskiwanych technologii na zdobywanie rynkowych przewag konkurencyjnych. Uzyskane wyniki badań potwierdzają występowanie tej zależności, choć jej siła - ku zaskoczeniu wydaje się raczej umiarkowana. Oznacza to, że rozwój tych zdolności $\mathrm{w}$ ramach potencjału absorpcyjnego przedsiębiorstw finansowych nie wywoła radykalnego zwiększenia posiadanych przez nie rynkowych przewag konkurencyjnych. Nieco silniejsze oddziaływanie zostało zidentyfikowane w przypadku łącznie analizowanych personalnych, jak również ogólnoorganizacyjnych składników zdolności eksploatacyjnych, a także niektórych wyspecjalizowanych w tym obszarze zasobów, w tym zwłaszcza powiązań systemu kontroli pracowników z systemem motywacyjnym.

\section{Słowa}

kluczowe: potencjat absorpcyjny, transfer technologii, przewaga konkurencyjna, zdolności.

\section{References}

1. Agmon T., von Glinow M.A. (1991), Technology transfer in international business, Oxford University Press, New York.

2. Barney J.B. (1997), Gaining and Sustaining Competitive Advantage, AddisonWesley Publishing Company, New York.

3. Cohen W.M., Levinthal D.A. (1990), Absorptive Capacity: A New Perspective on Learning and Innovation, "Administrative Science Quarterly", Vol. 35, No. 1.

4. Glabiszewski W. (2016), Potencjat absorpcyjny przedsiębiorstw finansowych $w$ Polsce $w$ procesie transferu innowacyjnych technologii, Wydawnictwo Naukowe UMK, Torun.

5. Grudzewski W.M., Hejduk I.K. (2008), Zarzadzanie technologiami. Zaawansowane technologie i wyzwania ich komercjalizacji, Difin, Warszawa.

6. Lasserre Ph. (2003), Global Strategic Management, Palgrave Macmillan, New York. 
7. Lowe P. (1999), Zarządzanie technologia. Możliwości poznawcze $i$ szanse, Wydawnictwo Śląsk, Katowice.

8. Pasternak K. (2005), Zarys zarzadzania produkcja, PWE, Warszawa.

9. Rutka R. (2002), Organizacja, [in:] A. Czermiński, M. Czerska, B. Nogalski, R. Rutka, J. Apanowicz, Zarzadzanie organizacjami, TNOiK „Dom Organizatora", Torun.

10. Trott P. (2008), Innovation Management and New Product Development, Prentice Hall, Harlow.

11. Tourangeau R., Conrad F.G., Couper M.P. (2013), The science of web surveys, Oxford University Press, Oxford.

12. Wasilewska E. (2008), Statystyka opisowa nie tylko dla socjologów. Teoria, przykłady, zadania, Wydawnictwo SGGW, Warszawa.

13. Wiśniewska J. (2015), Technologia jako strategiczny czynnik innowacyjności organizacji, [in:] J. Wiśniewska, K. Janasz (eds.), Innowacje i procesy transferu technologii w strategicznym zarzadzaniu organizacjami, Wydawnictwo Difin, Warszawa. 